\section{Effects of Manure, Straw and Inorganic Fertilizers on Northern Great Plains Ranges}

\section{S. SMOLIAK ${ }^{1}$}

Range Specialist, Canada Agriculture Research Station, Lethbridge, Alberta.

\section{Highlight}

One application of manure, straw and straw-plus-fertilizer increased forage production significantly up to eight years after treatment. Forage on these plots generally contained greater amounts of nutrients than on control plots and the species composition was changed. Fertilization is a valuable range management technique for increasing livestock production.

One method of increasing range forage production is by the use of barnyard manure and inorganic fertilizers. Substantial forage yield increases from applications of barnyard manure and inorganic fertilizers on Northern Great Plains have been shown in recent literature. The

${ }^{1}$ Formerly at Canada Experimental Farm, Manyberries, Alberta. benefits derived from applications of barnyard manure have not been separated to indicate whether the nutrients within the manure, the mulch effect resulting from the scattered manure, or a combination of the two factors brought about the increases in production.

Clarke, Tisdale and Skoglund (1943) reported that one application of 12 tons manure per acre more than doubled the forage yield of Bouteloua-Stipa vegetation over a six-year period. Later work at the same location, by Peters et al. (1953), showed that when manure was applied at the rate of 30 tons per acre the forage yield increase was greater than when rates of 15 or 7.5 tons were used. Studies conducted by Lodge (1959) on Stipa-Bouteloua range showed that manure applied at rates of 10 and 20 tons per acre increased crude protein content the first year and increased forage yield the second year.

In tests with inorganic fertilizers, Clarke and Tisdale (1945), Westin, Buntley and Brage (1955), Rogler and Lorenz (1957), Lodge (1959), and Cosper and Thomas (1961) have shown that nitrogen fertilizers increased forage yields and that the fertilized forage contained more protein. Phosphorus fertilizers, in some instances, increased the phosphorus contents of the fertilized forage.

Changes in botanical composition of the sward after nitrogen fertilization were shown by Rogler and Lorenz (1957). Western wheatgrass (Agropyron smithii) benefited most from the fertilizer, while blue grama (Bouteloua gracilis) decreased in density because of the shading effect and competition of western wheatgrass. Applications of manure at 10 tons per acre, to StipaBouteloua vegetation, were shown by Heady (1952) to be effective in improving the grass stand and in decreasing the amounts of little clubmoss (Se- 
laginella densa). Studies in areas other than the Northern Great Plains show that changes in botanical composition were induced by fertilization. Klipple and Retzer (1959), working on blue grama range in northwestern Colorado, found that density and growth of palatable grasses and annual forbs varied with the fertilizer treatment. Patterson and Youngman (1960) found that increased rates of nitrogen aided cheatgrass (Bromus tectorum), at the expense of native species, on central Washington ranges. Rumberg and Cooper (1961) showed that the botanical composition of a native meadow in Oregon was radically changed by the application of nitrogen and phosphorus fertilizers.

Heady (1956) found that the amount and position of mulch influenced the botanical composition of a California annualtype grassland. Some species were favored by complete removal of mulch, others with nonremoval and still others responded with intermediate mulch treatments. The position and height of mulch had a direct influence on the growth, yield and density of plants.

The study reported herein was conducted at the Experimental Farm, Manyberries, Alberta. The objective was to determine the effects of single applications of manure, straw and inorganic fertilizers on the yield and chemical and botanical composition of Bouteloua-Stipa range.

\section{Procedure}

The test was laid out in 1950 on a relic area protected from grazing for 20 years. The vegetation included the dominants, blue grama and needle-andthread (Stipa comata), along with western wheatgrass, Junegrass (Koeleria cristata), Sandberg bluegrass (Poa secunda), Plains reedgrass (Calamagrostis montanensis) and some sedges (Carex spp.). Little clubmoss, fringed sage (Artemisia frigida) and winterfat (Eurotia lanata) were present. The soil is a light loam, with a solonized profile, within the chestnut or brown soil zone. The climate is characteristic of the semi-arid Northern Great Plains region, with great extremes in temperatures, low amounts of precipitation, high winds and high rates of evaporation. The long term annual and seasonal (May-June, inclusive) precipitation totals are 12.08 and 3.82 inches. During the study (1951-58) the annual and seasonal precipitation totals were 14.42 and 4.42 inches.

Five treatments were randomized in four replicates, with plots 10 by 50 feet in each treatment. The treatments were: control; 30 tons barnyard manure per acre; 30 tons wheat straw per acre; 30 tons straw per acre plus 300 pounds N, 150 pounds $\mathrm{P}_{2} \mathrm{O}_{5}$ and 300 pounds $\mathrm{K}_{2} \mathrm{O}$ per acre; and inorganic fertilizer alone. The inorganic fertilizer approximated the contents in 30 tons well-rotted barnyard manure, averaging 0.5 percent $\mathrm{N}$, 0.25 percent $\mathrm{P}_{2} \mathrm{O}_{5}$ and 0.5 percent $\mathrm{K}_{2} \mathrm{O}$. The inorganic fertilizers were sulfate of ammonia (21-0-0), ammonium phosphate (11-48-0) and potassium sulfate (0-0-48). The barnyard manure, straw and fertilizer were hand broadcast in September to a new series of plots each year, for four years, beginning in 1950 . Three 9.6 square-foot areas were har- vested in July each year from 1951 until 1958 within each plot for dry matter yield determinations. Chemical analyses were made on the mature forage samples obtained during the years 1951 to 1956 , inclusive. The botanical composition of the vegetation on each plot was determined by the point quadrat method during August, 1958.

\section{Results}

The application of manure, fertilizer and straw-plus-fertilizer significantly increased forage yields each year for eight successive years after treatment (Table 1). The straw treatment reduced yields slightly the first year after application but significantly increased yields from the fourth to the eighth year. The greatest first-year response to treatment was obtained from applications of inorganic fertilizer. The benefits from applications of organic constituents were not immediate but were extended over a long period.

Chemical analyses showed that the forage on the control plots generally contained lower percentages of crude protein, crude fibre, and phosphorus and higher percentages of nitrogen-free extract, ether extract and calcium than forage on the treated plots (Figure 1), excepting those treated with straw alone. Crude protein and phosphorus contents were significantly higher on the

\section{Table 1. Yield of forage (oven-dry) in pounds per acre by treatments, 1951 to 1958.}

\begin{tabular}{|c|c|c|c|c|c|c|c|c|}
\hline \multirow{2}{*}{$\begin{array}{c}\text { Yrs.after } \\
\text { treat- } \\
\text { ment }\end{array}$} & \multirow{2}{*}{$\begin{array}{l}\text { No. of } \\
\text { years } \\
\text { ave. }\end{array}$} & \multirow[b]{2}{*}{ Control } & \multirow[b]{2}{*}{ Manure 1} & \multirow[b]{2}{*}{ Straw $^{1}$} & \multirow{2}{*}{$\begin{array}{l}\text { Fer- } \\
\text { til- } \\
\text { izer }^{2}\end{array}$} & \multirow{2}{*}{$\begin{array}{c}\text { Straw }^{1-} \\
\text { plus- } \\
\text { fert. }^{2}\end{array}$} & \multicolumn{2}{|c|}{ L.S.D. } \\
\hline & & & & & & & $\mathrm{P}=0.05$ & $\mathrm{P}=0.01$ \\
\hline 1 & 4 & 742 & 986 & 576 & 1606 & 1236 & 106 & 142 \\
\hline 2 & 4 & 850 & 1476 & 934 & 1714 & 1877 & 202 & 269 \\
\hline 3 & 4 & 912 & 1797 & 1138 & 1868 & 2031 & 220 & 294 \\
\hline 4 & 4 & 972 & 1974 & 1370 & 1940 & 2021 & 171 & 228 \\
\hline 5 & 4 & 978 & 1912 & 1499 & 1648 & 1978 & 214 & 286 \\
\hline 6 & 3 & 974 & 1732 & 1342 & 1456 & 1670 & 207 & 278 \\
\hline 7 & 2 & 750 & 1373 & 1283 & 1244 & 1608 & 221 & 301 \\
\hline 8 & 1 & 660 & 1283 & 1234 & 1068 & 1271 & 376 & 529 \\
\hline
\end{tabular}




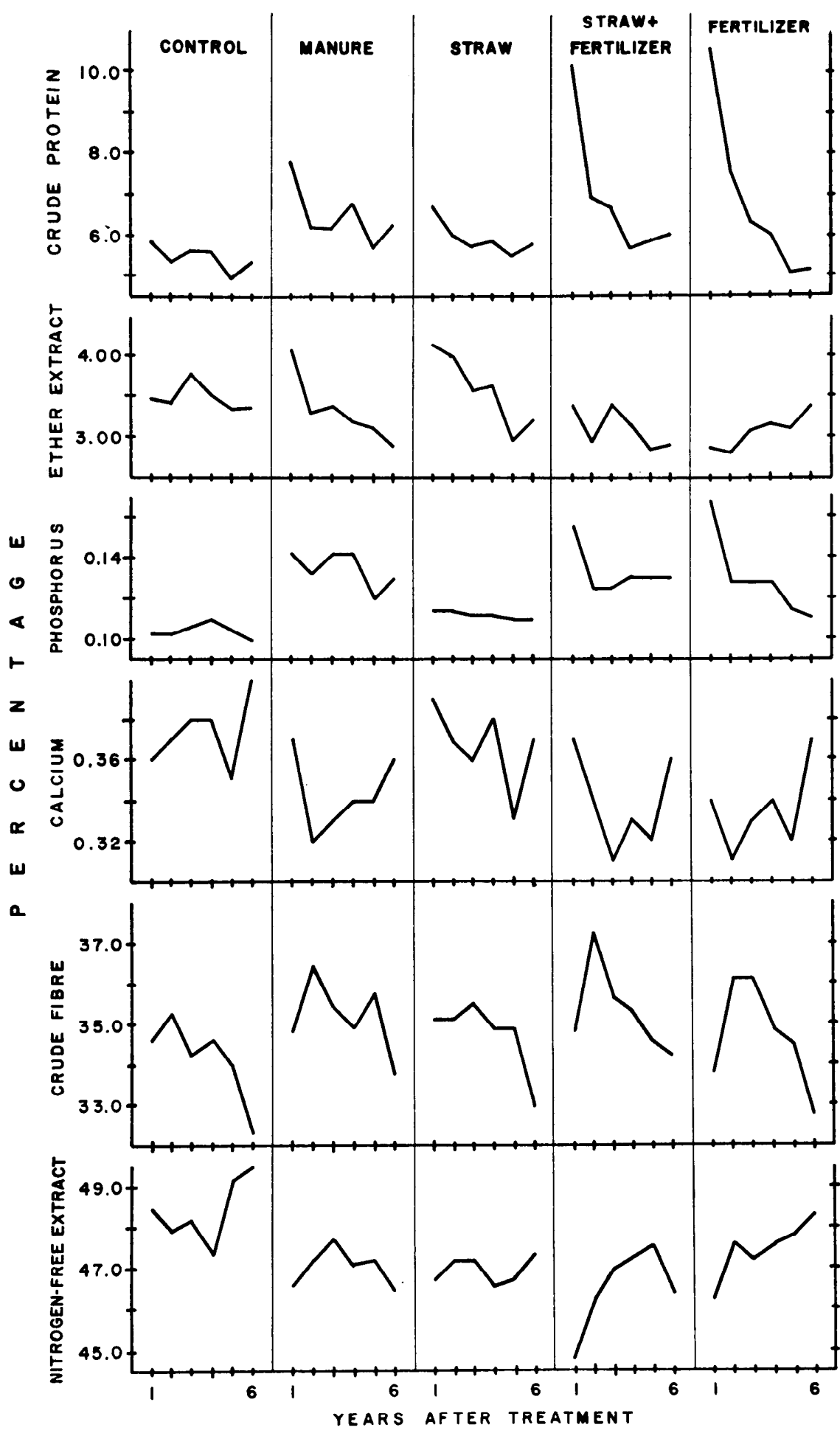

Figune 1. Pcrcentage of some chemical constituents in mature forage under various treatments 1 to 6 years after application.

manure, fertilizer and strawplus-fertilizer plots than on the control plots throughout the sixyear period. The percentage of crude fibre was significantly higher on the manure and strawplus-fertilizer plots than on the control plots. Ether extract content was significantly lower on the straw-plus-fertilizer and fertilizer plots than on the control plots. All lreated plots were significantly lower in nitrogen-free extract. Calcium content was significantly lower on the manure, straw-plus-fertilizer and fertilizer plots than on the control plots. The percentages of the various constituents, with the exception of nitrogen-free extract, in the forage on plots treated with straw alone did not differ significantly from those on the control plots.

Differences in the vegetative cover were found on the various plots five to eight years after being treated (Table 2). Percentage basal area of western wheatgrass was greater on the manure, straw, fertilizer and straw-plus-fertilizer treatments than on the control plots. Plains reedgrass increased in basal area on the straw-plus-fertilizer plots but decreased on the manure plots. Blue grama decreased in basal area on the manure and straw-plus-fertilizer plots while Junegrass and Sandberg bluegrass decreased on all treated plots. Total basal area of the grasses and sedges was lower on the manure and straw-plus-fertilizer plots than on the control plots. Fringed sage decreased on the manure, straw and strawplus-fertilizer plots. Moss phlox increased on all treated plots. The total basal area of the forbs and shrubs was lower on the manure, straw and straw-plus-fertilizer plots than on the control plots. Little clubmoss decreased on the manure, straw, fertilizer and straw-plus-fertilizer plots.

\section{Discussion}

Range fertilization trials, generally, have been concerned with relatively low rates of application. Within the Northern Great Plains region rates of fertilization ranged from 0 to 90 pounds of elemental fertilizer per acre. In this study inorganic fertilizer and manure were applied at higher rates: 300 pounds of nitrogen, 150 pounds of phosphate and 300 pounds of potash per acre. The immediate response from applications of inorganic 
Table 2. Basal area of the vegetation on plots receiving different treatments, August, 1958.

\begin{tabular}{|c|c|c|c|c|c|}
\hline Species & Control & Manure ${ }^{1}$ & Straw $^{1}$ & Fertilizer ${ }^{2}$ & $\begin{array}{c}\text { Straw }^{1} \\
\text { plus- } \\
\text { fertilizer }\end{array}$ \\
\hline & \multicolumn{5}{|c|}{$-\ldots-\cdots--($ Percent $)-\ldots-\cdots$} \\
\hline Blue grama grass & 2.33 & $1.42^{* *}$ & 2.23 & 2.23 & $0.63^{* *}$ \\
\hline Needle-and-thread grass & 2.36 & 2.40 & 2.46 & 2.56 & 2.42 \\
\hline Junegrass & 1.85 & $1.23 * *$ & $1.54 *$ & $1.54^{*}$ & $1.12 * *$ \\
\hline Western wheatgrass & 0.96 & $1.83^{* *}$ & $1.19^{*}$ & $1.35^{* *}$ & $1.77^{* *}$ \\
\hline Plains reed grass & 0.14 & $0.02^{*}$ & 0.25 & 0.23 & $0.42^{* *}$ \\
\hline Sandberg bluegrass & 0.12 & $0.02 * *$ & $0.04 * *$ & $0.06^{*}$ & $0.02 * *$ \\
\hline Sedges & 1.23 & $0.94^{*}$ & $1.61^{*}$ & 1.21 & 0.97 \\
\hline Total grasses and sedges & 8.99 & $7.86^{*}$ & 9.32 & 9.18 & $7.35^{* *}$ \\
\hline Fringed sage & 1.21 & $0.65^{* *}$ & $0.73^{* *}$ & 1.21 & $0.27 * *$ \\
\hline Winterfat & 0.23 & 0.17 & 0.17 & 0.02 & 0.21 \\
\hline Moss phlox & 0.17 & $0.06^{* *}$ & $0.02^{* *}$ & $0.08^{* *}$ & $0.08 * *$ \\
\hline Other forbs and shrubs & 0.08 & 0.14 & 0.20 & 0.18 & 0.10 \\
\hline Total forbs and shrubs & 1.69 & $1.02^{* *}$ & $1.12 * *$ & 1.49 & $0.66^{* *}$ \\
\hline Little clubmoss & 8.04 & $0.83^{* *}$ & $0.19 * *$ & $5.04 * *$ & $0.00 * *$ \\
\hline
\end{tabular}

130 tons per acre.

2300 lbs. $\mathrm{N} ; 150$ lbs. $\mathrm{P}_{2} \mathrm{O}_{5} ; 300$ lbs. $\mathrm{K}_{2} \mathrm{O}$ per acre.

*, ** Significantly different from control, $\mathrm{P}<0.05$ and 0.01 , respectively.

fertilizer was demonstrated by increases in forage yield and in percent crude protein. Response from applications of barnyard manure was evident in the immediate increase in percent crude protein. The higher rates of fertilization had no deleterious effects upon the vegetative growth; therefore, it is conceivable that even higher rates may be applied in future trials.

The use of a mulch was an effective means of increasing forage production. The artificial mulch, contributed by the straw, suppressed forage growth the first year after application, but with subsequent decay and disintegration its effectiveness was pronounced. This humic mulch formed a layer 1 to 1.5 inches in depth. In studies on mixed grass prairie in South Dakota, Larson and Whitman (1942) showed that forage yields varied directly with the depth of a natural mulch. The importance of natural mulches in promoting infiltration of rainfall, in prevention of erosion and in general maintenance of normal plantsoil-water relations has been shown in the literature.

The benefits derived from ap- plications of manure are due to the nutrients and to the mulch contributed by this form of fertilizer. The slow release of nutrients from within the manure influences forage production during the first few years, while the mulch influence is of greater significance in later years.

Changes in the botanical composition of the vegetation were induced by the organic and inorganic treatments. Blue grama, a dominant species, was replaced by western wheatgrass when additional nutrients and mulch were added. The decrease in basal area of blue grama was due to a better plant-soil-water relation; it also may have been affected by the shade of the taller, more vigorous species (Weaver, 1954; Rogler and Lorenz, 1957). Weaver (1954) found that blue grama succumbed after two or three years of dense shading. The reduction in basal area of fringed sage on the plots with organic treatments indicates that a mulch is detrimental to the development of this forb. The artificial mulch, also, was detrimental to the growth of little clubmoss which was almost eliminated on plots receiving the organic treatments.

The beneficial effects resulting from fertilization indicate that it can be utilized as a range management technique in increasing production of livestock. Higher yields of a more nutritious forage were obtained up to eight years after fertilization. The differential response of some species to fertilization and mulching makes possible the improvement in rangelands. However, it is possible that changes in botanical composition would have been different in a grazed sward.

\section{Summary}

Manure, straw and straw-plusfertilizer treatments increased forage production significantly up to eight years after fertilization. Forage on plots treated with manure, fertilizer and straw-plus-fertilizer generally contained higher amounts of crude protein, crude fibre and phosphorus and lower amounts of nitrogen-free extract, ether extract and calcium than forage on control plots. There was a differential species response to the additional nutrients and mulch supplied by the organic and inorganic treatments. Blue grama decreased while western wheatgrass increased in basal area on plots treated with manure and straw-plus-fertilizer. Basal area of little clubmoss was reduced substantially on the manure, straw and straw-plus-fertilizer treatments.

Response from applications of straw was attributed to the mulch effect provided by this treatment. Response from applications of barnyard manure was due to the nutrients and to the mulch supplied by the manure.

Fertilization can be employed as a range management technique to increase livestock production through increased forage yields, through the increased nutritional qualities of the forage, and through the induced changes in the botanical composition of the sward. 


\section{Literature cited}

Clark, S. E., and E. W. Tisdale. 1945. The chemical composition of native forage plants of southern Alberta and Saskatchewan in relation to grazing practices. Can. Dept. of Agr. Pub. 769 . 60 pp.

Clarke, S. E., E. W. Tisdale and N. A. Skoglund. 1947. The effects of climate and grazing practices on short-grass prairie vegetation. Can. Dept. of Agr. Pub. 747. 54 pp.

Cosper, H. R., and J. R. Thomas. 1961. Influence of supplemental runoff water and fertilizer on production and chemical composition of native forage. Jour. Range Mangt. 14: 292-297.

Heady, H. F. 1952. Reseeding, fertilizing and renovating in an ungrazed mixed prairie. Jour. Range Mangt. 5: 144-149.
Heady, H. F. 1956. Changes in a California annual plant community induced by manipulation of natural mulch. Ecology 37: 798-812.

Klipple, G. E., and J. L. REtzer. 1959. Response of native vegetation of the Central Great Plains to applications of corral manure and commercial fertilizer. Jour. Range Mangt. 12: 239-243.

LARSON, F., AND W. WhitMan. 1942. A comparison of used and unused grassland mesas in the Badlands of South Dakota. Ecology 23: 438445.

LodGe, R. W. 1950. Fcrtilization of native range in the Northern Great Plains. Jour. Range Mangt. 12: 277-279.

Patterson, J. K., AND V. E. YoungMAN. 1960. Can fertilizers effectively increase our range land pro- duction? Jour. Range Mangt. 13: 255-257.

Peters, H. F., J. B. McArthur, W. A. HUbbard AND S. SMOliak. 1955. Progress report, 1948-1953, Range Experimental Farm, Manyberries, Alberta. $45 \mathrm{pp}$.

ROGLER, G. A., AND R. J. LORENz. 1957. Nitrogen fertilization of Northern Great Plains rangelands. Jour. Range Mangt. 10: 156-160.

RUMBerg, C. B., aNd C. S. CoOper. 1961. Fertilizer induced changes in botanical composition, yield and quality of native meadow hay. Ägron. Jour. 53: 255-258.

WEAVER, J. E. 1954. North American prairie. Johnsen Publishing Co. Lincoln, Nebr. 269-270.

Westin, F. C., A. J. Buntley ANd B. L. Brage. 1955. Soil and weather. So. Dak. Agr. Exp. Sta. Cir. 116. Agr. Res. 6-18. 